\title{
Suicide Ideation and Depression among High- School Students in Mexico
}

Ideación Suicida y Depresión entre estudiantes de Secundaria en México

Ideação suicida e depressão entre alunos do ensino médio no México

\author{
José María de la Roca Chiapas ${ }^{1}$ \\ Iliana Pamela Tapia Ibarra ${ }^{2}$ \\ José Eduardo Huerta Lepez ${ }^{3}$ \\ Daniel Paramo Castillo 4 \\ Víctor Ramos Frausto ${ }^{5}$ \\ Lucia Pérez Sanchez ${ }^{6}$
}

Recibido: 27 de noviembre de 2019

Aprobado: 14 de abril de 2020

Publicado: 20 de mayo de 2020

Cómo citar este artículo:

De la Roca Chiapas, J.M., Tapia Ibarra P., Huertas-Lépez J.E., Páramo Castillo, D.,

Ramos Frausto, V. y Pérez, L. (2020). Suicide Ideation and Depression among High-School Students in Mexico. Pensando Psicología, 16(1), 1-17. doi: https://doi.org/10.16925/2382-3984.2020.01.05

Artículo de investigación. https://doi.org/10.16925/2382-3984.2020.01.05

1 Universidad de Guanajuato, Departamento de Psicología, Campus León ORCID: https://orcid.org/0000-0002-2563-403X

Correo electrónico: josema_delaroca@yahoo.com.mx

2 Universidad de Guanajuato, Departamento de Psicología, Campus León ORCID: https://orcid.org/0000-0002-7933-282X

3 Universidad de Guanajuato, Departamento de Psicología, Campus León ORCID: https://orcid.org/0000-0002-6920-4672

4 Universidad de Guanajuato, Departamento de Psicología, Campus León ORCID: https://orcid.org/0000-0002-1792-0861

5 Universidad de Guanajuato, Departamento de Psicología, Campus León ORCID: https://orcid.org/0000-0001-9815-4777

$6 \quad$ Universidad Autónoma de Nayarit, Departamento de Psicología ORCID: https://orcid.org/0000-0003-1614-7587 


\section{Abstract}

Purpose: To analyse the levels of depression and its influence on the presence of suicide ideation among high-school students.

Methods: cross-sectional, observational, and comparative study. The sample included 447 students who answered the following: the Beck Depression Inventory, the Beck Scale for Suicide Ideation, the Hamilton Scale for depression and a risk factor questionnaire elaborated ex professor. Statistical analysis included a description of variables, Pearson's correlation coefficient, and multiple regression.

Results: Sixty-six students (14.8\%) presented with suicide risk and 29 had made a suicide attempt. Almost 34\% of the students presented some level of depression according to the Hamilton Scale.

Conclusions: There is a strong correlation between suicidal behaviours and depression. It is important to raise awareness of the early signs of depression as a risk factor that may potentiate the risk of a suicide attempt.

Keywords: Depression, High-School Students, Suicide Attempt, Suicidal Ideation.

\section{Resumen}

Propósito: analizar los niveles de depresión y su influencia en la presencia de ideación suicida entre estudiantes de secundaria.

Métodos: es un estudio transversal, observacional y comparativo. La muestra incluyó 447 estudiantes que respondieron: el inventario Beck de depresión, la escala Beck de ideación suicida, la escala Hamilton para la depresión y un cuestionario de factor de riesgo elaborado por un profesor. El análisis estadístico incluyó descripción de variables, un coeficiente de correlación de Pearson y una regresión múltiple.

Resultados: sesenta y seis (14.8\%) estudiantes presentaron riesgo suicida y 29 han hecho un intento. Casi $34 \%$ de los estudiantes presentaron algún grado de depresión de acuerdo con la escala Hamilton.

Conclusiones: hay una correlación fuerte entre la depresión y el comportamiento suicida. Es importante hacer conciencia de los signos tempranos de depresión como un factor que puede potenciar el riesgo de intentos de suicidio.

Palabras clave: depresión, estudiantes de secundaria, intento suicida, ideación suicida.

\section{Resumo}

Objetivo: Analisar os níveis de depressão e sua influência na presença de ideação suicida em estudantes do ensino médio.

Métodos: estudo transversal, observacional e comparativo. A amostra incluiu 447 alunos que responderam: o Inventário de Depressão de Beck, a Escala de Ideação de Suicídio de Beck, a Escala de Hamilton para depressão e um questionário de fatores de risco elaborado ex professor. A análise estatística incluiu uma descrição das variáveis, coeficiente de correlação de Pearson e regressão múltipla.

Resultados: Sessenta e seis estudantes (14,8\%) apresentaram risco de suicídio e 29 já haviam feito tentativa de suicídio. Quase 34\% dos alunos apresentaram algum nível de depressão de acordo com a Escala de Hamilton. Conclusões: Existe uma forte correlação entre comportamentos suicidas e depressão. É importante aumentar a conscientização sobre os primeiros sinais de depressão como fator de risco que pode potencializar o risco de tentativa de suicídio.

Palavras-chave: Depressão, Alunos do Ensino Médio, Tentativa de Suicídio, Ideação Suicida. 
José María de la Roca Chiapas, Iliana Pamela Tapia Ibarra, José Eduardo Huerta Lepez, 3 Daniel Paramo Castillo, Víctor Ramos Frausto, Lucia Pérez Sanchez

\section{Introduction}

In the majority of cases, suicide is not an impulsive act and many actions are associated with suicidal behaviour. Suicidal ideation is the conscious desire to take one's own life, which includes planning how it will be carried out (Thompson, Dewa \& Phare, 2012). The risk of actually making a suicide attempt increases when a person has made a concrete plan to end his or her life; therefore, it is important to identify early signs of suicidal behaviour. This point view, known as the suicide continuum, has been used in a wide range of studies and practical prevention programs. This is especially true when depression is a central variable in the studied persons (Sveticic \& De Leo, 2012) because it allows us to order behaviours that are considered suicide risk factors. In general, the continuum includes the following stages: suicidal ideation, suicide plan, suicide attempt, and eventually, completed suicide.

Other suicide risk factors have been studied but they are not always are part of a theory and are not well understood, such as how they interact with other variables or in specific populations. Anxiety disorders, PTSD, drug use disorders, and sexual abuse history have all been investigated to differentiate suicide ideators from suicide attempters (May \& Klonsky, 2016). Specifically, Mexican adolescents present with risk factors, englobed as psychosocial problems, such as: drug use (including alcohol and tobacco), depression symptoms, and previous suicide attempts (González-Forteza, Juárez-López, Jiménez, Montejo-León, Rodríguez-Santisbón \& Wagner, 2017). Family factors including conflictive relationships with their father/mother, or parental conflicts have also been previously detected among Mexican students (González, Ramos, Caballero \& Wagner, 2003). and high levels of stress in their daily activities also has been previously detected in Mexican students (González, Ramos, Caballero \& Wagner, 2003; De la Roca-Chiapas, et al, 2019).

The World Health Organization (WHO) calculates that the worldwide age-standardized suicide rates for 2012 was 11.4 per 100,000; this represents 1.4\% of global mortality and is the 15th leading cause of death (WHO, 2014). In the United States, suicide is the tenth leading cause of death, the third leading cause of death for children aged 10-14, and the second for young people aged 15-34 (National Institute of Mental Health, 2018). In Mexico, it is also the 15th leading cause of death (INEGI, 2016), the 9th among 5-14 year-olds and the fifth main cause of death in adults aged 15-49 (Institute for Health Metrics and Evaluation, 2018). In recent years, both the prevalence and health impact of suicide have increased in Mexico (INEGI, 2016; Dávila, Ochoa \& Casique, 2015). Unfortunately, suicide records do not consider suicide attempts or suicidal ideation, two important risk factors for suicide (WHO, 2014). A study conducted in Mexico City showed that $7.2 \%$ of adolescents aged $12-17$ presented with suicide 
ideation without suicide attempt or behaviour during the year prior to the investigation (Borges et al., 2010). At the local level, a study conducted in 2004 among high-schoollevel students at the University of Guanajuato found that just over 8\% of students had thought about committing suicide within the week preceding the investigation (Chávez, Pérez, Macías \& Páramo, 2004).

Suicide in adolescents is not only a public health problem. Is also a complex phenomenon when transitions between developmental stages, psychological distress or even personal crisis and psychopathology co-occur, especially when we realize the phenomenon that occurs when there is suicidal ideation but that even the literature is not yet conclusive when affirming that it can be an antecedent of attempted suicide or of completed suicide. It is considered that the manner via which problems are resolved during this stage will directly influence their mental health as adults (De Hepcée, Reynaert, Jacques \& Zdanowicz, 2015; Miranda \& Shaffer, 2013). This is a period of vulnerability during which the adolescent struggles to fulfil the new demands of daily life and stressful events potentiate the risk of presenting suicidal behaviour (Leveton, 1987; De la Roca-Chiapas, 2008).

\section{Methods}

Our study was cross-sectional, observational, and comparative. Our main goal was to analyse the levels of depression and its influence on the presence of suicidal ideation in high school students in the city of Leon, Guanajuato.

Four high-schools participated in the study, among which we selected a representative and random sample from each grade. The sample included 447 students, who were assessed using the following tests:

- $\quad$ The Beck Scale for Suicide Ideation (SSI); developed to identify the presence and quantify the severity of suicide ideation.

- The Beck Depression Inventory (BDI); designed to assess the severity (the intensity of symptoms) of depression in the preceding week.

- $\quad$ The Hamilton Rating Scale for Depression (HRSD); designed to provide a measure of the intensity or severity of depression during the preceding month.

Additionally, we developed and implemented a questionnaire based on a review of the literature on the risk factors associated with suicidal behaviours. The participants had to respond if they had lived through or were currently experiencing the 
José María de la Roca Chiapas, Iliana Pamela Tapia Ibarra, José Eduardo Huerta Lepez, Daniel Paramo Castillo, Víctor Ramos Frausto, Lucia Pérez Sanchez

situations described in each item. This questionnaire consisted of 24 items, including the questions "have you ever considered committing suicide?" and "have you ever tried to commit suicide?" The items included in this questionnaire and the answers given by students are shown in table 1. A scale to assess the level of risk presented by the participant was developed based on the responses to these two questions, in combination with the results of the ssI.

Table 1. General results.

\begin{tabular}{|c|c|c|c|c|}
\hline & $\begin{array}{l}\text { General results } \\
\qquad(n=447)\end{array}$ & $\begin{array}{c}\text { Gender } \\
\text { (female/male) }\end{array}$ & $\begin{array}{l}\text { Suicide ideation } \\
\text { (SSI) }(n=66)\end{array}$ & $\begin{array}{l}\text { Suicide attempt } \\
\qquad(n=29)\end{array}$ \\
\hline $\begin{array}{l}\text { History of mental illness in } \\
\text { the family }\end{array}$ & $11 \%(50)$ & $\begin{array}{l}12.5 \%(33 / 263) \\
6.5 \%(17 / 184)\end{array}$ & $21 \%(14)$ & $45 \%(13)$ \\
\hline $\begin{array}{l}\text { Drug abuse by family } \\
\text { members }\end{array}$ & $32 \%(142)$ & $\begin{array}{l}33.1 \%(87 / 263) \\
29.9 \%(55 / 184)\end{array}$ & $45 \%(30)$ & $59 \%(17)$ \\
\hline $\begin{array}{l}\text { Suicide or suicide attempt } \\
\text { by family members }\end{array}$ & $11 \%(47)$ & $\begin{array}{c}12.9 \%(34 / 263) \\
7.1 \%(13 / 184)\end{array}$ & $12 \%(8)$ & $28 \%(8)$ \\
\hline $\begin{array}{l}\text { Presence of guns in the } \\
\text { household }\end{array}$ & $8 \%(34)$ & $\begin{array}{l}7.2 \%(19 / 263) \\
8.2 \%(15 / 184)\end{array}$ & $12 \%(8)$ & $7 \%(2)$ \\
\hline $\begin{array}{l}\text { Divorce or parental sepa- } \\
\text { ration }\end{array}$ & $16 \%(71)$ & $\begin{array}{l}15.2 \%(40 / 263) \\
16.8 \%(31 / 184)\end{array}$ & $30 \%(20)$ & $45 \%(13)$ \\
\hline $\begin{array}{l}\text { Recent death of family or } \\
\text { friends }\end{array}$ & $33 \%(148)$ & $\begin{array}{l}31.9 \%(84 / 263) \\
34.8 \%(64 / 184) \\
\end{array}$ & $36 \%(24)$ & $41 \%(12)$ \\
\hline Drug abuse & $13 \%(60)$ & $\begin{array}{l}12.2 \%(32 / 263) \\
15.2 \%(28 / 184) \\
\end{array}$ & $21 \%(14)$ & $38 \%(11)$ \\
\hline Sleep trouble & $27 \%(121)$ & $\begin{array}{l}27.8 \%(73 / 263) \\
26.1 \%(48 / 184)\end{array}$ & $44 \%(29)$ & $62 \%(18)$ \\
\hline Headache & $36 \%(163)$ & $\begin{array}{l}46.8 \%(123 / 263) \\
21.7 \%(40 / 184)\end{array}$ & $55 \%(36)$ & $66 \%(19)$ \\
\hline Lack of motivation & $30 \%(134)$ & $\begin{array}{l}32.7 \%(86 / 263) \\
26.1 \%(48 / 184)\end{array}$ & $55 \%(36)$ & $52 \%(15)$ \\
\hline Lack of concentration & $35 \%(155)$ & $\begin{array}{l}41.8 \%(110 / 263) \\
24.5 \%(45 / 184)\end{array}$ & $53 \%(35)$ & $55 \%(16)$ \\
\hline $\begin{array}{l}\text { Economic problems in the } \\
\text { family }\end{array}$ & $45 \%(200)$ & $\begin{array}{l}48.7 \%(128 / 263) \\
39.1 \%(72 / 184)\end{array}$ & $50 \%(33)$ & $66 \%(19)$ \\
\hline Loss of appetite & $23 \%(103)$ & $\begin{array}{l}64.6 \%(70 / 263) \\
17.9 \%(33 / 184)\end{array}$ & $32 \%(21)$ & $38 \%(11)$ \\
\hline Weight gain & $11 \%(47)$ & $\begin{array}{c}13.7 \%(36 / 263) \\
6 \%(11 / 184)\end{array}$ & $21 \%(14)$ & $24 \%(7)$ \\
\hline Weight loss & $12 \%(54)$ & $\begin{array}{l}13.3 \%(35 / 263) \\
10.3 \%(19 / 184)\end{array}$ & $18 \%(12)$ & $21 \%(6)$ \\
\hline Poor school performance & $45 \%(199)$ & $\begin{array}{c}46.8 \%(123 / 263) \\
41.3 \%(76 / 184)\end{array}$ & $45 \%(30)$ & $59 \%(17)$ \\
\hline Loss of interest & $20 \%(89)$ & $\begin{array}{l}23.2 \%(61 / 263) \\
15.2 \%(28 / 184)\end{array}$ & $38 \%(25)$ & $34 \%(10)$ \\
\hline
\end{tabular}

(continúa) 


\begin{tabular}{lcccc}
\hline & $\begin{array}{c}\text { General results } \\
\text { (n= 447) }\end{array}$ & $\begin{array}{c}\text { Gender } \\
\text { (female/male) }\end{array}$ & $\begin{array}{c}\text { Suicide ideation } \\
\text { (SSI) (n= 66) }\end{array}$ & $\begin{array}{c}\text { Suicide attempt } \\
\text { (n = 29) }\end{array}$ \\
\hline Feeling depressed & $30 \%(133)$ & $\begin{array}{c}34.6 \%(91 / 263) \\
22.8 \%(42 / 184)\end{array}$ & $61 \%(40)$ & $76 \%(22)$ \\
\hline Recent stressful event & $46 \%(206)$ & $\begin{array}{l}51 \%(134 / 263) \\
39.1 \%(72 / 184)\end{array}$ & $58 \%(38)$ & $69 \%(20)$ \\
\hline Has considered commit- & $23 \%(104)$ & $\begin{array}{l}27.8 \%(73 / 263) \\
16.8 \%(31 / 184)\end{array}$ & $62 \%(41)$ & $97 \%(28)$ \\
ting suicide & $6 \%(29)$ & $\begin{array}{l}8 \%(21 / 263) \\
4.3 \%(8 / 184)\end{array}$ & $26 \%(17)$ & - \\
\hline $\begin{array}{l}\text { Previous suicide attempt } \\
\text { Was sexually abused }\end{array}$ & $3 \%(14)$ & $\begin{array}{l}4.6 \%(12 / 263) \\
1.1 \%(2 / 184)\end{array}$ & $6 \%(4)$ & $17 \%(5)$ \\
\hline $\begin{array}{l}\text { Parental support percei- } \\
\text { ved }\end{array}$ & $93 \%(416)$ & $\begin{array}{c}92.4 \%(243 / 263) \\
94 \%(173 / 184)\end{array}$ & $82 \%(54)$ & $69 \%(20)$ \\
\hline $\begin{array}{l}\text { Parental rejection per- } \\
\text { ceived }\end{array}$ & $3 \%(15)$ & $\begin{array}{l}4.2 \%(11 / 263) \\
2.2 \%(4 / 184)\end{array}$ & $9 \%(6)$ & $24 \%(7)$ \\
\hline
\end{tabular}

Source: Own elaboration.

Data were analysed using a description of variables, Pearson's correlation coefficient, and multiple regression to evaluate the associated factors. The confidence interval was set at $95 \%$ and $p$ values $<0.05$ were considered significant.

This study meets the standards established in the Declaration of Helsinki for Human Scientific Research. The protocol was submitted and approved by the participating high-schools. All students provided informed consent prior to inclusion in the study, stating their voluntary participation and anonymity.

\section{Results}

\section{Descriptive Analysis}

The age range of the students was 14-18 years (average, 16 years). Fifty-nine percent of the participants (263) were female. Sixty-eight students (15.2\%) reported having symptoms of 'mild depression' during the week prior to the investigation, 23 participants (5.1\%) had symptoms of 'moderate depression', and six students (1.3\%) presented symptoms of 'major depression' during this period, according to the BDI. The results of the HRSD showed that 20.3\% (91 students) of the sample exhibited symptoms of 'minor depression' during the month prior to the investigation, 8.3\% (37 participants) reported symptoms of 'less than major depression', and 5.4\% (24) had symptoms of 'major depression.' 
José María de la Roca Chiapas, Iliana Pamela Tapia Ibarra, José Eduardo Huerta Lepez, 7 Daniel Paramo Castillo, Víctor Ramos Frausto, Lucia Pérez Sanchez

When asked whether they had considered committing suicide in the past, 23\% (104 students) of the sample responded affirmatively. Among these individuals, 73 were female (27.8\% of the total women included in the study) and 31 were male $(16.8 \%$ of the male participants). When asked if they had tried to commit suicide, 6\% (29 students) of the sample responded that they had made at least one suicide attempt in the past. Twenty-one of these individuals were women (7.9\% of the female sample) and eight were men (4.3\% of the male sample). The SSI showed that $14.8 \%$ of the participants (66 students) had suicide ideation at the time of the study; forty-five of them were female.

\section{Correlations}

We used Pearson's correlation coefficient to assess the presence of correlations between risk factors and the presence of suicidal ideation and suicide attempt. The correlations were considered significant at $p<0.05$ and are listed in table 2 . The strongest correlations were found between the presence of suicidal ideation (SSI) and the lack of motivation, loss of interest, feeling depressed, suicidal thoughts, suicide attempt, perceived rejection by parents, and ratings on the two depression scales (these correlations showed $p<0.001)$.

Table 2. Correlations between risk factors and the presence of suicide ideation and suicide attempt.

\begin{tabular}{lcc}
\hline & $\mathbf{R}^{\mathbf{2}}$ & $\boldsymbol{p}$ \\
\hline Variables associated with the Scale for Suicide Ideation (SSI) & & $<.001$ \\
Beck Depression Inventory (BDI) & 0.196 & $<.001$ \\
Hamilton Rating Scale for Depression (HRSD) & .010 \\
History of mental illness in the family & 0.167 & .010 \\
Drug abuse by family members & 0.015 & .001 \\
Divorce or parental separation & 0.015 & .044 \\
Drug abuse & 0.024 & .001 \\
Sleep trouble & 0.009 & .001 \\
Headache & 0.023 & $<.001$ \\
Lack of motivation & 0.024 & .002 \\
Lack of concentration & 0.049 & .005 \\
Weight gain & 0.022 & $<.001$ \\
Loss of interest & 0.018 & $<.001$ \\
Feeling depressed & 0.040 & \\
\hline
\end{tabular}


(viene)

\begin{tabular}{|c|c|c|}
\hline & $\mathbf{R}^{2}$ & $p$ \\
\hline Recent stressful event & 0.023 & .001 \\
\hline Has considered committing suicide & 0.146 & $<.001$ \\
\hline Previous suicide attempt & 0.089 & $<.001$ \\
\hline Parental support perceived & 0.024 & .001 \\
\hline Parental rejection perceived & 0.032 & $<.001$ \\
\hline \multicolumn{3}{|l|}{ Variables associated with previous suicide attempt } \\
\hline Beck Depression Inventory & 0.094 & $<.001$ \\
\hline Hamilton Rating Scale for Depression & 0.303 & $<.001$ \\
\hline Scale for Suicide Ideation & 0.089 & $<.001$ \\
\hline History of mental illness in the family & 0.088 & $<.001$ \\
\hline Drug abuse by family members & 0.017 & .006 \\
\hline Suicide or suicide attempt by family members & 0.017 & .005 \\
\hline Divorce or parental separation & 0.032 & $<.001$ \\
\hline Recent death of family or friends & 0.009 & .042 \\
\hline Drug abuse & 0.029 & $<.001$ \\
\hline Sleep trouble & 0.032 & $<.001$ \\
\hline Headache & 0.029 & $<.001$ \\
\hline Lack of motivation & 0.011 & .025 \\
\hline Economic problems in the family & 0.014 & .012 \\
\hline Loss of appetite & 0.014 & .012 \\
\hline Weight gain & 0.009 & .042 \\
\hline Weight loss & 0.011 & .028 \\
\hline Feeling depressed & 0.085 & $<.001$ \\
\hline Recent stressful event & 0.014 & .013 \\
\hline Has considered committing suicide & 0.175 & $<.001$ \\
\hline Was sexually abused & 0.028 & $<.001$ \\
\hline Parental support perceived & 0.030 & $<.001$ \\
\hline Parental rejection perceived & 0.071 & $<.001$ \\
\hline
\end{tabular}

Source: Own elaboration.

The variables associated with previous suicide attempt were the ratings on the two scales of depression, presence of suicidal ideation in the SSI, a family history of mental disorder, separation of the parents, drug use, sleep trouble, headache, feeling depressed, suicidal thoughts, previous sexual abuse, and perceived rejection by parents $(p<0.001)$.

Considering only those participants with suicidal ideation in the SSI $(n=66)$, there was a strong correlation between the BDI and HRSD, weight gain, feeling depressed, previous suicide attempt, and perceived support from parents $(p<0.001)$. 
José María de la Roca Chiapas, Iliana Pamela Tapia Ibarra, José Eduardo Huerta Lepez, Daniel Paramo Castillo, Víctor Ramos Frausto, Lucia Pérez Sanchez

The variables associated with the HRSD were the BDI, feeling depressed, suicidal thoughts, and perceived parental support $(p<0.001)$. Having considered committing suicide exhibited strongest correlation with suicide attempt and the HRSD $(p<0.001)$, whereas having a previous suicide attempt showed a strong correlation with the BDI, separation of the parents, and suicidal thoughts $(p<0.001)$. These results are shown in Table 3.

Table 3. Correlations for participants with suicide ideation, using the Beck Scale for Suicide Ideation.

\begin{tabular}{|c|c|c|}
\hline & $\mathbf{R}^{2}$ & $p$ \\
\hline \multicolumn{3}{|c|}{ Variables associated with the Beck Depression Inventory } \\
\hline Hamilton Rating Scale for Depression & 0.548 & $<.001$ \\
\hline Divorce or parental separation & 0.121 & .004 \\
\hline Sleep trouble & 0.118 & .005 \\
\hline Headache & 0.101 & .009 \\
\hline Lack of motivation & 0.119 & .005 \\
\hline Lack of concentration & 0.099 & .010 \\
\hline Loss of appetite & 0.093 & .013 \\
\hline Weight gain & 0.212 & $<.001$ \\
\hline Loss of interest & 0.065 & .038 \\
\hline Feeling depressed & 0.243 & $<.001$ \\
\hline Has considered committing suicide & 0.153 & .001 \\
\hline Previous suicide attempt & 0.206 & $<.001$ \\
\hline Parental support perceived & 0.341 & $<.001$ \\
\hline Parental rejection perceived & 0.140 & .002 \\
\hline \multicolumn{3}{|c|}{ Variables associated with the Hamilton Rating Scale for Depression } \\
\hline Beck Depression Inventory & 0.549 & $<.001$ \\
\hline Sleep trouble & 0.086 & .017 \\
\hline Headache & 0.126 & .003 \\
\hline Lack of motivation & 0.081 & .020 \\
\hline Lack of concentration & 0.081 & .021 \\
\hline Loss of appetite & 0.110 & .006 \\
\hline Weight gain & 0.081 & .021 \\
\hline Feeling depressed & 0.276 & $<.001$ \\
\hline Recent stressful event & 0.072 & .029 \\
\hline Has considered committing suicide & 0.174 & $<.001$ \\
\hline Previous suicide attempt & 0.098 & .011 \\
\hline Parental support perceived & 0.298 & $<.001$ \\
\hline
\end{tabular}

(continúa) 
(viene)

\begin{tabular}{lcc}
\hline & $\mathbf{R}^{\mathbf{2}}$ & $\boldsymbol{p}$ \\
\hline Variables associated with having considered committing suicide & & .001 \\
Beck Depression Inventory & 0.153 & $<.001$ \\
Hamilton Rating Scale for Depression & 0.174 & .011 \\
Divorce or parental separation & 0.096 & .031 \\
Feeling depressed & 0.070 & .010 \\
Recent stressful event & 0.100 & $<.001$ \\
Previous suicide attempt & 0.211 & $<.001$ \\
\hline Variables associated with a previous suicide attempt & & .011 \\
Beck Depression Inventory & 0.205 & .002 \\
Hamilton Rating Scale for Depression & 0.097 & .015 \\
History of mental illness in the family & 0.139 & $<.001$ \\
Drug abuse by family members & 0.088 & .010 \\
Divorce or parental separation & 0.194 & .006 \\
Sleep trouble & 0.100 & .019 \\
Feeling depressed & 0.110 & $<.001$ \\
Recent stressful event & 0.083 & .020 \\
Has considered committing suicide & 0.211 & .027 \\
Was sexually abused & 0.082 & 0.074 \\
Parental rejection perceived & & \\
\hline
\end{tabular}

Source: Own elaboration.

The analysis of the data for the group of participants that reported having a previous suicide attempt $(n=29)$ revealed that the SSI was strongly correlated with the BDI ( $p=0.002)$ and the divorce of the parents $(p=0.009)$. The BDI exhibited a strong correlation with the HRSD $(p<0.001)$ and the perceived parental support $(p<0.001)$ (Table 4).

Table 4. Correlations for participants with previous suicide attempt.

\begin{tabular}{lcc}
\hline & $\mathbf{R}^{\mathbf{2}}$ & $\boldsymbol{p}$ \\
\hline Variables associated with Scale for Suicide Ideation & .032 \\
Age & 0.159 & .002 \\
Beck Depression Inventory & 0.308 & .018 \\
Hamilton Rating Scale for Depression & 0.191 & .009 \\
Divorce or parental separation & 0.226 & .019 \\
Recent stressful event & 0.187 & \\
\hline
\end{tabular}

(continúa) 


\begin{tabular}{lll}
\hline & $\mathbf{R}^{\mathbf{2}}$ & $\boldsymbol{p}$ \\
\hline Variables associated with Beck Depression Inventory & .002 \\
Scale for Suicide Ideation & 0.308 & $<.001$ \\
Hamilton Rating Scale for Depression & 0.535 & .005 \\
Presence of guns in the household & 0.262 & .024 \\
Divorce or parental separation & 0.175 & .016 \\
Recent death of family or friends & 0.196 & .012 \\
Lack of motivation & 0.211 & .015 \\
Weight gain & 0.199 & .020 \\
Feeling depressed & 0.184 & .002 \\
Parental support perceived & 0.299 & .018 \\
\hline Variables associated with Hamilton Rating Scale for Depression & & $<.001$ \\
Scale for Suicide Ideation & 0.191 & .032 \\
Beck Depression Inventory & 0.535 & .013 \\
Recent death of family or friends & 0.159 & .013 \\
Sleep trouble & 0.209 & .048 \\
Lack of motivation & 0.206 & .004 \\
Loss of appetite & 0.137 & 0.274 \\
Feeling depressed & 0.403 & \\
\hline Parental support perceived & & \\
\hline
\end{tabular}

Source: Own elaboration.

\section{Multiple Regression}

Because there were so many variables exhibiting significant correlations, we used multiple regression to determine whether there were correlations among these variables. In a first analysis, the SSI, the combination of the scales proposed in this study, and having a previous suicide attempt were significant risks for suicidal ideation $\left(R^{2}=\right.$ $.73, p<0.001)$. After the elimination of the instruments that evaluate suicidal ideation, results indicated that the HRSD, the BDI, having a history of mental illness in the family, having a previous suicide attempt, and perceiving parental support were significant risks for suicidal ideation $\left(R^{2}=.29, p<0.001\right)$. The solution of the statistical package Statistics 8.0 revealed a correlation between suicidal ideation, the BDI, and having a previous suicide attempt $\left(R^{2}=.28, p<0.001\right)$.

Regarding the presence of previous suicide attempts, multiple regression analysis of variables showed the presence of a correlation between this variable and a history of mental illness in the family, drug use, lack of motivation, feeling depressed, 
suicidal ideation, previous sexual abuse, and perceiving parental rejection $\left(R^{2}=0.27\right.$, $p<0.001)$ The last solution from the statistical program for this variable revealed the presence of a correlation with having suicidal ideation, a history of mental illness in the family, feeling depressed, perceived parental rejection, drug use, and previous sexual abuse $\left(R^{2}=0.22, p=0.006\right)$.

\section{Discussion and conclusions}

The results obtained here are consistent with the findings of González-Forteza et al. (2017), González-Forteza, Jiménez, and Bojorquez (2005) and Jiménez, Mondragon, and González-Forteza (2007) in Mexico, who demonstrated that depressive disorders and suicidal ideation are related to other suicidal behaviours in young adolescents. The specific relationship between depression and suicidal behaviour may be mediated by perceived burdensomeness (Kang, You, Huang, Ren, Lin \& Xu 2018) and social cognitions and maladaptive interpersonal behaviours (Dueweke \& Schwartz-Mette, 2017). In a similar way, neuroticism with its manifestations of anxiety and insecurity is highly correlated with suicidal ideation in young people (Huerta, De la Roca-Chiapas, Aguilar, Hernández \& Barbosa, 2016). The interaction between depression and suicide potentiates the risk of presenting other risk behaviours. Major depressive disorder is the most common psychiatric diagnosis associated with suicide. According to the American Association of Suicidology (2002), 75\% of people who commit suicide are depressed at the time of death. Similar data were obtained by Sánchez, Cáceres, and Gómez (2002) in a group of university students in Colombia, among whom most of the students with suicidal ideation were diagnosed as being in the depressive spectrum. The same study showed that the prevalence of suicidal ideation among these college students during the year prior to the investigation was 13\% and that it was more common in women. The present investigation found similar data: a prevalence of suicidal ideation of $12.7 \%$, which was more frequent in females. More recently, in Chile $26.3 \%$ of students in a study had attempted suicide at least once in their life, and $20 \%$ had suicidal thoughts (Barroilhet et al., 2012). It seems that the proportion of all types of suicidal behaviours is similar worldwide. Eskin et al. (2016) found that 29\% of university students from 12 countries have suicidal ideation at least once in their lifetimes, and $7 \%$ reported at least one suicide attempt.

Having made a previous suicide attempt has become an important predictor of suicide risk and suicide ideation (Thompson et al., 2012; Peña, Casas, Padilla, Gómez $\&$ Gallardo, 2002). Approximately $40 \%$ of people who commit suicide have tried it previously (Centers for Disease Control and Prevention, 2016), and $80 \%$ of men and $87 \%$ 
José María de la Roca Chiapas, Iliana Pamela Tapia Ibarra, José Eduardo Huerta Lepez, Daniel Paramo Castillo, Víctor Ramos Frausto, Lucia Pérez Sanchez

of women who died from suicide had already attempted suicide in the 12 months prior. Most scales that evaluate suicide risk attribute special importance to the history of suicide attempts, to determine the severity of suicide risk at a given point (Ghasemi, Shaghaghi \& Allahverdipour, 2015).

Another important factor that increases the risk of presenting suicidal behaviour is the use of drugs, as found by Schilling, Aseltine, Glanovsky, Jamesa, and Jacobs (2009), regarding the use of alcohol when feeling depressed; and by Zhang and Wu (2014), who demonstrated that cigarettes and alcohol use in adolescence increases. A history of sexual abuse is also important, as shown by Pérez-González and Pereda (2015) and Joiner et al. (2007), who found a correlation between sexual abuse and the number of suicide attempts.

It has been demonstrated that family has an important influence on the development of suicidal behaviour in adolescents, regarding both the presence of a history of mental illness in the family (National Institute of Mental Health, 2018; King, Kerr, Passarelli, Foster \& Merchant, 2010) and the relationships established between parents and children (Fotti, Katz, Afifi \& Cox, 2006). The results obtained in the present investigation are consistent with the study by Fotti et al. (2006), who found that adolescents who perceived their parents as being distant or uncaring presented a higher risk of committing suicide

Some studies suggest the existence of a sequence in suicidal behaviour, where suicidal ideation precedes behaviours such as suicidal threats or behaviours, suicide attempts, and, finally, suicide. However, most often, this behaviour goes unnoticed and it is not until a person makes a suicide attempt that he or she comes into contact with a health professional (Peña et al, 2002). For this reason, it is important to pay attention to the presence of risk factors, especially when it comes to adolescents. Given the characteristic vulnerability of this life stage, it is less likely that adolescents will seek help by their own means.

\section{Limitations}

The limitations of this study are the small sample size and possible bias in the answers, as the students knew from the informed consent letter that the results of the study may be shared with parents. There were a few cases in which parents did not give consent for the study, which may be due them not wanting to share information on risk conditions or family dynamic, or for fear of being stigmatised. 


\section{Conflict of Interest}

No conflict of interest declared.

\section{Acknowledgements}

We would like to express thanks to all the participants, their parents and the educational institutions that allowed the research.

\section{References}

American Association of Suicidology (2002). Facts about suicide. Retrieved from http://www.suicidology.org/c/document_library/get_file?folderld=232\&name=DLFE-88.pdf

Barroilhet, S., Fritsch, R., Guajardo, V., Martínez, V., Vöhringer, P., Araya, R. \& Rojas, G. (2012). Suicidal Ideation, Self-Directed Violence and Depression Among Chilean School Adolescents. Revista Médica Chilena, 140(7), 873-81.

Borges, G., Benjet, C., Medina-Mora, M., Orozco, R., Familiar, I., Nock, M., \& Wang, P. (2010). Service Use Among Mexico City Adolescents with Suicidality. Journal of Affective Disorders, 120, 32-39.

Centers for Disease Control and Prevention. (2016). Data \& Statistics Fatal Injury Report for 2015. Retrieved from https://www.cdc.gov/injury/wisqars/fatal.html

Chávez, A., Pérez, R., Macías, L. \& Páramo, D. (2004). Ideation and Suicide Attempts in High School Level Students at the Guanajuato University. Acta Universitaria, 14(3), 12-20.

Dávila, C., Ochoa, M. \& Casique, I. (2015). Análisis del impacto de la mortalidad por suicidios en México, 2000-2012. Salud Colectiva, 1(4), 471-84.

De Hepcée, C., Reynaert, C., Jacques, D. \& Zdanowicz, N. (2015). Suicide in Adolescence: Attempt to Cure a Crisis, but also the Fatal Outcome of Certain Pathologies. Psychiatria Danubina, 27 (Suppl 1), S296-299.

De la Roca-Chiapas, J. (2008). Psychoanalysis and Epidemiology of Suicide in the State of Guanajuato in the Period 1997-2001. Reflections on Youth Groups. Salud Pública, 50(1), 4-5.

Dueweke, A. \& Schwartz-Mette, R. (2017). Social-Cognitive and Social-Behavioral Correlates of Suicide Risk in College Students: Contributions from Interpersonal Theories of Suicide and Depression. Archives of Suicide Research, 22(2), 224-240. https://doi.org/10.1080/13811118. 2017.1319310 
José María de la Roca Chiapas, Iliana Pamela Tapia Ibarra, José Eduardo Huerta Lepez, 15 Daniel Paramo Castillo, Víctor Ramos Frausto, Lucia Pérez Sanchez

Eskin, M., Sun, J., Abuidhail, J., Yoshimasu, K., Kujan, O., Janghorbani, M., Flood, C., Giovanni, M., Tran, U., Mechri, A., Hamdan, M., Poyrazli, S., Aidoudi, K., Bakhshi, S., Harlak, H., Moro, M.F., Nawafleh, H., Phillips, L., Shaheen, A. Taifour, S., Tsuno, K. \& Voracek, M. (2016). Suicidal Behavior and Psychological Distress in University Students: A 12-Nation Study. Archives of Suicide Research, 20(3), 369-388. https://doi.org/10.1080/13811118.2015.1054055

Fotti, S., Katz, L., Afifi, T. \& Cox, B. (2006). The Associations Between Peer and Parental Relationships and Suicidal Behaviours in Early Adolescents. Canadian Journal of Psychiatry, 51(11), 698-703.

Ghasemi, P., Shaghaghi, A. \& Allahverdipour, H. (2015). Measurement Scales of Suicidal Ideation and Attitudes: A Systematic Review Article. Health Promotion Perspectives, 5(3), 156-168.

González-Forteza, C., Jiménez, A. \& Bojorquez, L. (2005). Género y suicidio en adolescentes: constructos entrelazados. In A. Chávez-Hernández (Ed.), Elección final: ensayos sobre suicidio y eutanasia en el mundo contemporáneo (pp. 167-168). México City: Universidad de Guanajuato.

Huerta, J., De la Roca-Chiapas, J.M., Aguilar, H., Hernández, M., Barbosa, S. (2016). Factores de personalidad asociados al intento suicida en adolescentes leoneses. In C., Solano, M. Sánchez, G. Vázquez, A. Martínes, \& J. Esquivás, J. (Eds.), Compendio de investigaciones científicas en México (pp. 2409-2414). Guanajuato, México: Centro de Investigaciones en Óptica A.C.

Instituto Nacional de Estadística y Geografía (INEGI) (2016). Estadísticas a propósito del día mundial de la prevención del suicidio. Retrieved from http://www.inegi.org.mx/saladeprensa/aproposito/2016/suicidio2016_0.pdf

Institute for Health Metrics and Evaluation. (2018). Global Burden Disease. Retrieved from https:// vizhub.healthdata.org/gbd-compare/

Jiménez,A., Mondragon, L., \&González-Forteza,C. (2007). Self-Esteem, DepressiveSymptomatology, and Suicidal Ideation in Adolescents: Results of Three Studies. Salud Mental, 30(5), 20-26.

Joiner, T., Sachs-Ericssona, N., Wingatea, L., Browna, J., Anestisa, M. \& Selbya, E. (2007). Childhood Physical and Sexual Abuse and Lifetime Number of Suicide Attempts: A Persistent and Theoretically Important Relationship. Behaviour Research and Therapy, 45, 539-547.

Kang, N., You, J., Huang, J., Ren, Y., Lin, M.P. \& Xu, S. (2018). Understanding the Pathways from Depression to Suicidal Risk from the Perspective of the Interpersonal-Psychological Theory of Suicide. Suicide and Life-Threatening Behavior, 48(3), 684-694. https://doi.org/10.1111/ sltb.12455 
King, C., Kerr, D., Passarelli, M., Foster, C., \& Merchant, C. (2010). One-Year Follow-Up of Suicidal Adolescents: Parental History of Mental Health Problems and Time to Post-Hospitalization Attempt. Journal of Youth and Adolescence, 39, 219-232.

Leveton, E. (1987). El adolescente en crisis. Mexico City: Editorial Pax.

Miranda, R. \& Shaffer, D. (2013). Understanding the Suicidal Moment in Adolescence. Annals of the New York Academy of Sciences, 1304, 14-21.

National Institute of Mental Health. (2018). Suicide in the U.S.: Statistics and Prevention. Retrieved from https://www.nimh.nih.gov/health/statistics/suicide.shtml

Peña, L., Casas, L., Padilla, M., Gómez, T. \& Gallardo, M. (2002). Behavior of Suicide Attempts in a Group of Adolescents and Youth. Revista Cubana de Medicina Militar, 31, 182-187.

Pérez-González, A. \& Pereda, N. (2015). Systematic Review of the Prevalence of Suicidal Ideation and Behavior in Minors Who Have Been Sexually Abused. Actas españolas de psiquiatría, 43(4), 149-58.

Sánchez, R., Cáceres, H. \& Gómez, D. (2002). Suicidal Ideation in Adolescent University Students: Prevalence and Associated Factors. Biomédica, 22, 407-416.

Schilling, E., Aseltine, R., Glanovsky, J., Jamesa, A. \& Jacobs, D. (2009). Adolescent Alcohol Use, Suicidal Ideation, and Suicide Attempts. Journal of Adolescent Health, 44, 335-341.

Thompson, A., Dewa, C. \& Phare, S. (2012). The Suicidal Process: Age of Onset and Severity of Suicidal Behaviour. Social Psychiatry and Psychiatric Epidemiology, 47(8), 1263-1269.

World Health Organization (2014). Preventing Suicide: A Global Imperative. Geneve: WHO.

Zhang, X. \& Wu, L. (2014). Suicidal Ideation and Substance Use Among Adolescents and Young Adults: A Bidirectional Relation? Drug and Alcohol Dependence,142, 63-73. 


\section{Annex 1: Questionnaire*}

\section{Questionnaire}

INSTRUCTIONS: Carefully read each question and answer sincerely, remember that your answers will remain confidential and anonymous.

Note: It is important for us that you include your name but you can omit it if you wish.

Name:

Age:

Sex:

\begin{tabular}{|c|c|c|c|}
\hline & Question & YES & NO \\
\hline 1 & Does someone in your family have a history of mental illness? & & \\
\hline 2 & Does someone in your family abuse any drug, substance, or alcohol? & & \\
\hline 3 & Has someone in your family attempted suicide? & & \\
\hline 4 & Are there firearms in your house? & & \\
\hline 5 & $\begin{array}{l}\text { Have you experienced or are you experiencing a divorce or separation between your } \\
\text { parents? }\end{array}$ & & \\
\hline 6 & Has a family member or friend died recently? & & \\
\hline 7 & Have you used or consumed some kind of drug? & & \\
\hline 8 & Do you have trouble sleeping? & & \\
\hline 9 & Do you have frequent headaches? & & \\
\hline 10 & Have you felt bored lately, listless, or have no motivation? & & \\
\hline 11 & Do you find it difficult to concentrate? & & \\
\hline 12 & Have you seen or do you feel that there are economic problems in your family? & & \\
\hline 13 & Have you lost your appetite lately? & & \\
\hline 14 & Have you gained a lot of weight? ( $10 \%$ of your body weight in the last month) & & \\
\hline 15 & Have you lost weight lately? (10\% of your body weight in the last month) & & \\
\hline 16 & Have you failed any subjects in the past year? & & \\
\hline 17 & Have you lost interest in certain actitivites, such as sports, going out with friends, school? & & \\
\hline 18 & Have you felt depressed in the last three months? & & \\
\hline 19 & Has something happened that you consider particularly stressful in the last month? & & \\
\hline 20 & Have you thought about suicide? & & \\
\hline 21 & Have you tried to kill yourself? & & \\
\hline 22 & Were you a victim of rape or some kind of sexual abuse? & & \\
\hline 23 & Do you feel that your parents support you? & & \\
\hline 24 & Or the contrary, do you feel rejected by them? & & \\
\hline
\end{tabular}

* Translated from the original Spanish for publication. 